\title{
Setting Organisational Culture to Develop Potential and Innovativeness
}

\author{
DOI: 10.12776/QIP.V24I1.1346
}

\author{
Lucie Vnoučková, Hana Urbancová
}

Received: 2019-11-18 Accepted: 2020-03-11 Published: 2020-03-31

\begin{abstract}
Purpose: The article aims to identify approaches influencing impact of organisational culture on development of innovation potential in organisations.

Methodology/Approach: The data were obtained by questionnaire survey in organisations operating in the Czech Republic $(n=207)$ that represented all sectors of Czech economy.

Findings: In today's highly competitive environment, organisations need to focus on setting an organisational culture that will support the development of all employees' knowledge and potential. The results have shown that the surveyed organisations are characterised by two basic approaches to setting the organisational culture for creating innovations: either an emphasis on relationships and collaboration or an emphasis on productivity.

Research Limitation/implication: The limit of the article may be seen in a relatively small sample of respondents; however, with respect to the stratified sampling the sample is representative.

Originality/Value of paper: The contribution of this paper lies in the identification and evaluation of approaches to support innovation potential based on type of organisational culture. The practical contribution lies in identification of approaches used to set efficient organisational culture and in presenting concrete results from real organisations that redesigned their culture and identified efficient variables for its design and implementation. The results are important for development of efficient approaches to organisational culture.
\end{abstract}

Category: Research paper

Keywords: quality; efficiency; innovation; organisation; productivity; approach 


\section{INTRODUCTION}

In today's competitive environment innovations developed in organisations help to develop competitiveness. Innovations support improvement of processes and increase product efficiency. Innovations drives competitive advantage thanks to development of new products, services, efficient process set-up, etc. that enable organisations to meet customer needs in the shortest time and as best as possible (Adams, et al., 2019; Corstjens, Carpenter and Hasan, 2019; Grinza and Quatraro, 2019; Bocken et al., 2014).

The growing importance of information, knowledge and innovation in today's competitive environment has brought fast process of interrelated changes impacting each employee of an organisation, individual teams and the entire organisation (Cerne, Jaklic and Skerlavaj, 2013; Avolio, Walumbwa and Weber, 2009). To develop innovation potential, every organisation needs knowledge, new skills, flexible working conditions and setting of organisational climate and culture that support development of innovations and each individual's innovation potential. Every employee is a bearer of knowledge and has potential that an organisation can use to its advantage. So far, research results show that innovation activities of organisations are limited by lack of qualified human resources in organisations (Hitka et al., 2017; Diesel and Scheepers, 2019; Acebo and Viltard, 2018; Kampf, Hitka and Ližbetinová, 2019; Kiron et al., 2013).

Skilled human resources, individual employees of organisations, are absolutely necessary and irreplaceable when creating innovations, quality research and development, and implementing innovation processes. However, employees' knowledge, skills and abilities must be developed continuously (Urbancová, 2013; Stachová and Kachaňáková, 2011). Therefore, it must be stated that in order to remain competitiveness, it is essential that employees need to be able to continue their learning, improve their qualifications and capitalise their potential (Nidumolu, Prahalad and Rangaswami, 2009; Cerne, Jaklic and Skerlavaj, 2013; Avolio, Walumbwa and Weber, 2009). The right set up of organisational culture plays important role in organization and has important implications for managerial action in area of employee development and using of their potential. However, research on the links between culture and innovation remains limited.

The article aims to identify approaches influencing impact of organisational culture on development of innovation potential in organisations.

The article consists of four main parts. The first part summarise theoretical assumptions and leads to synthesis of the latest research findings in the given field. Chapter Methodology describes research methods and procedures. Results present research outcomes and implications. Discussion presents comparison of achieved results with similar researches in the studied field. Particular recommendations for organisations are presented in Conclusions section. 


\subsection{Theoretical Background}

The shorter expiry-time of information, constant need to expand knowledge and skills and rapid development of ICT have completely rebuilt labour market by reducing number of low-skilled jobs and increasing number of jobs with high demands of skills, competences and education together with necessity of flexibility. This has resulted not only in the change in the work life in organisations but also in a greater emphasis on continuous development of every individual and focus on innovations (Geradts and Bocken, 2019; Jin, Navare and Lynch, 2019; Huo, Motohashi and Gong, 2019). The cultural context in which an organisation operates influences the level of innovation (Lijauco et al., 2020). Organisations need to adapt to modern trends in management, continual changes in markets and external environment, and these changes must be reflected in an organisational environment setting (Chen et al., 2018; Stankiewicz and Lychmus, 2017). Also, organizational sustainability significantly intervenes in the interaction of organizational culture and innovation (Srisathan, Ketkaew and Naruetharadhol, 2020). It is necessary to realise that innovation is in its core applied new knowledge, which is a valuable organisational resource linked to human element, since the bearer of knowledge is always and employee.

In the globalised economic environment, not only organisations but also entire states compete, and their competitiveness no longer depends solely on material resources, but primarily on employee knowledge, knowledge creation, its preservation and sharing, and, last but not least, its use. Continuous development, increasing individual knowledge, skills, qualifications and experience will improve the innovation potential of individuals, teams and organisations in all types of innovation that are distinguished in practice which is confirmed by atuhors (Leopold, 2019; Hollensbe et al., 2014; Cerne, Jaklic and Skerlavaj, 2013; Bocken et al., 2014; Stachová, Stacho and Vicen, 2017).

First and foremost, employees can help their organisation to effectively set processes (process innovations) by implementation of their ideas, for example by introducing new or improved production or delivery methods. Employee commitment to organisational culture impacts knowledge creation, and openness to change, and positively influence employees' knowledge creation (Chai, Song and You, 2020). Significant effect of organizational culture on organizational sustainability in cultural characteristics and to maintain the core business competencies as marketing, operations, customer orientation, and financial management (Srisathan, Ketkaew and Naruetharadhol, 2020). This innovation type can lead to reduction in material consumption and labour costs for the organisation and to improvement in working conditions for employees, etc. The result is a profit growth, possibility to launch new variants of the marketing strategy compare to competition, etc. In addition, employees can use their ideas to assist in marketing innovations by introducing new marketing methods that an organisation has not used yet (e.g. redesigning product and its packaging, placing it on the market through new sales channels, new pricing strategy, etc.). To use current innovations and to support employees' potential for new innovations, the 
type of organisational innovation is very important. In this area, a new organisational method is introduced in business practices of the organisation, in structure of jobs or in external relations (e.g. by creating a new type of cooperation with suppliers). Last but not least, it is necessary to mention product innovations that improve organisation's market position (Grinza and Quatraro, 2019; Adams et al., 2016; Bocken et al., 2014). The fact that an organisation comes up with a new product or service brings about several advantages, primarily in building a brand, not only of the product/service, but also the employer's brand.

Without employees and their knowledge, however, organisations will find it very difficult to achieve innovations, as innovators are mostly talents that need to be constantly developed and supported in their creativity and their activities by suitable set working and organisational conditions (Urbancová, 2013). It is necessary to realise that organisation's performance is not exceeding based on its resources it has, but it depends mainly on quality of its employees. People working in organisation and having the same values as management are the most valuable capital. When managing innovations themselves, it is necessary to maintain a rational attitude of organisation's management towards innovations, i.e. to continually model situations of threats, to consider risks, and last but not least, to think about new products and innovation of every area In organisation. Again, it is up to employees - high-quality managers to reveal weak, sometimes hidden signals that customers send to express their needs, and to be able to search for them. In other words, nowadays it is impossible to innovate within organisations without high-quality employees (Lenihan, McGuirk and Murphy, 2019; Wei, Kang and Wan, 2019; Geradts and Bocken, 2019; Acebo and Viltard, 2018).

Culture is usually manifested through the beliefs and values related to various organizational aspects which influence the overall performance, outputs and innovations in an organisation (Lijauco et al., 2020). To ensure that employees can be continuously developed, it is necessary to set the appropriate organisational culture which supports employee development and considers reasonable expenses on development. The expenses dedicated to employee development can be considerd as an investment that will return to organisation (Liao, 2018; Messick et al., 2019). If organisational climate and organisational culture are set improperly inefficient use of working time, problems and conflicts in the workplace, employee turnover and ineffective communication can occur instead of innovations and progressive use of employees' innovation potential and labour productivity (Leopold, 2019; Kiron et al. al., 2013; Nidumolu, Prahalad and Rangaswami, 2019). From the organisation's perspective, current organisational culture should be in harmony with strategically designed organisational culture. The nature of current organisational culture can be overcome by changes in organisation's economic, social or technical environment and by change in its market position by a takeover or merge (Messick et al., 2019; Wei, Kang and Wan, 2019; Acebo and Viltard, 2018). 
The relationship between organisational culture and innovation has recently been increasingly monitored and researched by many authors worldwide. Many researchers focus on research in various environments and sectors, regions and states, especially in developed countries, but there are also studies mapping the influence of organisational culture on innovation in developing countries, as reported by Sánchez-Báez, Fernández-Serrano and Romero (2019), Büschgens, Bausch and Balkin (2013), and Lemon and Sahota (2004). However, research in this area in the Czech Republic has not been conducted yet. Since organisational culture is specific to every organisation and represents a fundamental principle of functioning of an organisation, it is necessary to pay attention to it. The effectiveness with which culture is used in an organisation is reflected in organisation's ability to achieve results and innovations (Martins and Terblanche, 2003). The external organisational culture, i.e. the one perceived by competitors, potential customers and employees plays an important role in every organisation. Every organisation is perceived by its stakeholders through selected elements of culture and one of them is employee development and innovation potential. These elements of culture influence the brand of an organisation either in a positive or negative sense. This impacts an organisation's position in the market and also possible recruitment and retention of high-quality and talented employees with potential. To develop their innovation potential, organisations need knowledge, abilities and skills of their employees. Therefore, innovations can only be achieved when employees' potential is continuously developed and increased. Based on above mentioned, this article deals with setting a suitable organisational culture that supports employee development and their innovation potential.

\section{METHODOLOGY}

The data were obtained by quantitative research focused on innovations and innovation potential by means of a questionnaire survey in $n=207$ organisations. In total, 860 e-mails to owners or management of organisations were sent out, 207 returned. The e-mail return rate was $24.06 \%$. The sample was selected from the Albertina database of organisations. The quota sample size was defined using the Krejcie and Morgan (1970) formula $(\mathrm{N}=2,700,000)$ from Albertina database, with required confidence level at $95 \%$ (standard value of 1.96 ), the acceptable deviation rate $=0.03$ and the expected deviation rate $r=0.04$ ). Using this statistical approach to the sample size based on the above-mentioned rates was met by the conducted survey $(n=207)$. The minimum number of respondents was set at 164 .

The questionnaire was filled by middle or higher management of addressed organisations, in case of smaller organisation the owner himself filled the questionnaire (the responses therefore reflected the point view of organisational heads/owners/managers). The questionnaire respected the ethical aspect and anonymity of respondents. The survey contained 16 questions: 4 identification 
questions (sector, area of business activities, size, part of a larger organisation) and 12 research questions which are further processed evaluated in this article. All questions were closed-ended (allowing only one response, multiple choice) and with more response options.

Pilot survey was used to test the questionnaire. Small sample of organisational representatives were asked to fill the questionnaire and the questions and possible answers were discussed with them. Based on this feedback, the final questionnaire was adjusted and finalized.

The questionnaire focused on the following areas: importance of innovations in organisation, importance of development and maintain innovative culture, support of innovative culture in organisation, sources used to stimulate innovation, problem solving at individual level in organisation, common way of project and task solving, top areas of innovation in organisation, identification of groups of employees involved in innovation process, procedure of employee involvement in innovation processes, characterization of a typical manager focusing on innovations, importance of ergonomics in organisation, system of ergonomics in organisation and ways of its ensuring.

The structure of respondents $(n=207)$ was as follows:

- Sector: $81.6 \%$ - private; $18.4 \%$ - public;

- Internationalisation: 45.4\% - international organisation; $12.6 \%$ - local organisation; $27.5 \%$ - national organisation; $14.5 \% \quad-$ regional organisation;

- Part of group of organisations: $44.9 \%$ is part of a larger group; $55.1 \%$ is single owned;

- Size of the organisation: $21.3 \%$ with 1 - 9 employees; $26.1 \%$ with 10 - 49 employees; $23.2 \%$ with 50 - 249 employees; $29.5 \%$ with 250 and more employees.

The following null hypotheses were tested:

$H_{0}$ 1: There is no significant dependence between focus of organisational culture and sector where an organisation operates.

$H_{02}$ : There is no significant dependence between focus of organisational culture and market (national vs. international).

$\mathrm{H}_{0} 3$ : There is no significant dependence between focus of organisational culture and ownership of an organisation.

$H_{04}$ : There is no significant dependence between focus of organisational culture and size of the organisation (number of employees).

The results were analysed using statistical tools - the dependence test $(\chi 2)$ and the power of dependence test (Cramer's V). In cases where the determined pvalue was below the significance level of $\alpha=0.05$, the null hypothesis was 
rejected because data demonstrated statistical dependence between qualitative variables. In such cases, the strength of dependence was determined using Cramer's V coefficient. The strength of correlation was interpreted in accordance with the categories of De Vaus (2014). For the purposes of the dependence test, the responses in the questionnaire were merged into dichtomic structure (answer was marked or was not marked).

To identify further relationships between variables, factor analysis (multivariate statistics) was used based on adequate quality of dependencies found in the data matrix. The factor analysis was conducted after the correlation analysis and the principal component analysis. We used the Varimax method and the KaiserGuttman rule for selection of significant variables to form factors according to Anderson (2009). The factor was considered for further evaluation only if the value was greater than 1 (initial loading); values of variables exceeding 0.3 were considered significant to form the factor.

The statistical software used to evaluate the data was IBM SPSS Statistics 24 .

\section{RESULTS}

Based on the results, it can be summarised that the surveyed organisations have their organisational cultures set to support knowledge and experience sharing among employees in order to strengthen innovation potential of individuals, teams and the entire organisation. Representatives of organisations were asked which operating areas were innovated. Representatives could select more answers. The results shown that organisations surveyed mostly innovated working procedures $(24.9 \%)$, quality of work $(19.3 \%)$, labour productivity (16.7), and the portfolio of products and services (12.7\%).

To specify setting of organisational culture in line with the focus on the type of innovations, dependencies between organisational characteristics were determined, see Table 1 .

The Table 1 shows dependencies between setting of organisational culture and the fact whether the organisation is part of a multinational company and size of the organisation (the strength of dependence ranges from 0.192 to 0.323 , which is a weak to medium dependence).

The results show that setting of organisational culture affects the decline in labour productivity $(5.6 \%)$, efficient use of working time (14.8\%), problematic interpersonal relationships in the workplace (16.7\%), high staff turnover (11.1\%), insufficient communication between individual organisational units $(22.2 \%)$, discrepancy between the current culture of organisation and strategically needed organisational culture (7.4\%), overcoming the nature of current organisational culture by changes in economy, social or technical environment of organisation $(16.7 \%)$ and change in the market position of organisation by an acquisition and/or merge $(5.5 \%)$. 
Table 1 - Dependencies between Focus of Organisational Culture and Selected Qualitative Characteristics (Source: Authors' Own Calculation based on Survey)

\begin{tabular}{|l|c|c|c|c|c|c|}
\hline \multirow{2}{*}{$\begin{array}{l}\text { Focus of } \\
\text { organisatio } \\
\text { nal culture }\end{array}$} & \multirow{2}{*}{$\begin{array}{c}\text { Absolute } \\
\text { frequencies }\end{array}$} & $\mathbf{\%}$ & \multicolumn{4}{|c|}{ Dependence of the organisation on: } \\
\cline { 3 - 7 } & & Sector & Market & Ownership & Size \\
\cline { 3 - 7 } & & \multicolumn{4}{|c|}{ Relationship (p-value/Cramer's V) } \\
\hline $\begin{array}{l}\text { Orientation } \\
\text { on results }\end{array}$ & 51 & 24.6 & $\begin{array}{c}\mathrm{NO} \\
(0.880)\end{array}$ & $\begin{array}{c}\text { YES } \\
(0.022 / 0.211)\end{array}$ & $\begin{array}{c}\text { YES } \\
(0.003 / 0.201)\end{array}$ & $\begin{array}{c}\text { YES } \\
(0.000 / 0.323)\end{array}$ \\
\hline $\begin{array}{l}\text { Orientation } \\
\text { on customer }\end{array}$ & 44 & 21.3 & $\begin{array}{c}\mathrm{NO} \\
(0.177)\end{array}$ & $\mathrm{NO}(0.103)$ & $\begin{array}{c}\text { YES } \\
(0.005 / 0.192)\end{array}$ & $\begin{array}{c}\text { YES } \\
(0.021 / 0.211)\end{array}$ \\
\hline $\begin{array}{l}\text { Orientation } \\
\text { on quality }\end{array}$ & 48 & 23.2 & $\begin{array}{c}\mathrm{NO} \\
(0.441)\end{array}$ & $\mathrm{NO}(0.282)$ & $\mathrm{NO}(0.142)$ & $\begin{array}{c}\text { YES } \\
(0.006 / 0.237)\end{array}$ \\
\hline $\begin{array}{l}\text { Orientation } \\
\text { on } \\
\text { innovation }\end{array}$ & 28 & 13.5 & $\begin{array}{c}\mathrm{NO} \\
(0.652)\end{array}$ & $\mathrm{NO}(0.164)$ & $\mathrm{YES}$ & $\begin{array}{c}\text { YES } \\
(0.001 / 0.233)\end{array}$ \\
\hline $\begin{array}{l}\text { No focus on } \\
\text { innovation }\end{array}$ & 36 & 17.4 & $\mathrm{x}$ & $\mathrm{x}$ & $\mathrm{x}$ & $\mathrm{x}$ \\
\hline
\end{tabular}

To examine the mutual relationships between variables in more detail, the data were processed using multivariate statistics according to Anderson (2009); the factor analysis identified 2 factors influencing aspects of organisational culture (see Table 2).

Table 2 - Variance Explained by Factors (Source: Authors' Own Calculation based on Survey)

\begin{tabular}{|c|c|c|c|}
\hline Factor & Total Variance & Total \% of Variance & Cumulative \% of Variance \\
\hline 1 & 3.977 & 49.717 & 49.717 \\
\hline 2 & 1.131 & 14.134 & 63.851 \\
\hline
\end{tabular}

The factor analysis identified 2 significant factors combining analysed variables. The first factor explains approximately $50 \%$ of the sample, the second factor $14 \%$. Table 3 shows the results of the factor analysis in detail. The areas described in methods section on organisational culture were examined.

According to the results shown in Table 3, respondents in the sample can be divided into two groups. The first group of variables comprises variables of organisational climate setting, primarily based on interpersonal relationships (0.743), appropriate communication (0.858) and changes in the social, economic and technical environment of organisation that affect staff turnover (0.779). These areas, including communication, relationships and staff turnover, contribute to the primary reason to reset organisational culture of almost half of surveyed organisations. The identified factor can be named "Organisational 
Culture Supporting Collaboration" and it explains $49.717 \%$ of sample. It is obvious that variables related to employees and their satisfaction within organisation are essential. The lack of emphasis on communication and relationships often results in staff turnover. If an organisation realizes this mistake, a new setting of organisational culture is effective tool to eliminate negative areas. This leads to ideal use of human resources that subsequently creates innovations. A functioning organisational culture involving collaboration, high-quality relationships and communication leads to knowledge and information sharing, creativity and value creation for an organisation.

Table 3 - Resultant Factors Determined by the Varimax Method (Source: Authors' Own Calculation based on Survey)

\begin{tabular}{|c|c|c|}
\hline Variable & Factor 1 & Factor 2 \\
\hline Decline in labour productivity & 0.062 & 0.903 \\
\hline Efficient use of working time & 0.464 & 0.711 \\
\hline Problematic interpersonal relationships in the workplace & 0.743 & 0.174 \\
\hline High staff turnover & 0.779 & 0.175 \\
\hline $\begin{array}{l}\text { Insufficient communication between individual } \\
\text { organisational units }\end{array}$ & 0.858 & 0.316 \\
\hline $\begin{array}{l}\text { Discrepancy between the current culture of organisation } \\
\text { and strategically needed organisational culture }\end{array}$ & 0.235 & 0.769 \\
\hline $\begin{array}{l}\text { Overcoming the nature of current organisational culture by } \\
\text { changes in economy, social or technical environment of } \\
\text { organisation }\end{array}$ & 0.473 & 0.430 \\
\hline $\begin{array}{l}\text { Change in the market position of organisation, acquisition } \\
\text { and/or merge }\end{array}$ & 0.662 & 0.134 \\
\hline Total \% of Variance & 49.717 & 14.134 \\
\hline Name of the factor & $\begin{array}{l}\text { Culture } \\
\text { supporting } \\
\text { collaboration }\end{array}$ & $\begin{array}{l}\text { Culture } \\
\text { supporting } \\
\text { productivity }\end{array}$ \\
\hline
\end{tabular}

In contrast, the second identified factor involves re-setting of the organisational culture based on decrease in the labour productivity (0.903), efficient use of working time (0.711) and setting of a strategically effective organisational culture (0.769). The factor focuses on development of employee potential through a suitable working environment that supports knowledge and experience sharing and innovation potential. The identified factor that characterises approximately $15 \%$ of sample can be named "Organisational Culture Supporting Productivity". It can be stated that in this case organisational culture is set up to 
increase labour productivity, not the area of internal collaboration, as was the case of the first factor.

Both factors characterise the strategic approach of using organisational culture to enhance organisation's ability to work more efficient and to generate innovations. Either in terms of interconnection and collaboration of employees, or in terms of efficient use of time and thus increasing the labour productivity. The results develop practice in defining key criteria of innovative approach to build organisational culture and its efficient use to support innovations. The results may inspire other researchers to conduct further research in other conditions and deepen the knowledge of the relationship between organisational culture and innovation potential.

\section{DISCUSSION}

Nowadays, innovation is an indisputable part of modern society and a prerequisite for long-term competitiveness, both for individual organisations or states, as confirmed by conclusions of Kiron et al. (2013) or Grinza and Quatraro (2019). Innovation is an intentionally proposed change, with which, however, only employees of organisations can come up with, as stated by authors Urbancová (2013), Hitka et al. (2019). The change organisations focus on depends on abilities of employees and it relates to products and services, manufacturing processes or management methods used in an organisation for the first time. In the official statistical survey of the Czech Statistical Office, innovations in organisations are monitored at the technical (product and process) and non-technical (marketing and organisational) levels.

As stated by the Czech Statistical Office (2019), the innovation activity of organisations in the Czech Republic in 2016 increased for the first time since the economic crisis, mainly due to the growing efforts of small organisations. Also, for the first time, more financial resources were invested in the research and development than in the so-called non-knowledge innovations. But it is still not enough to match the European Union average.

Czech Statistical Office (2019) also published innovation activities of Czech organisations from 2014 to 2016 . The data clearly show that in the mentioned period $46.3 \%$ of Czech organisations innovated their products, processes, marketing or organisational methods. Compared to the period of 2012-2014, this is an increase in innovation activity of organisations by $4 \%$. Thus, the negative trend of a decline in innovation activities brought about by the economic crisis in 2008 has stopped. However, it is necessary to realise that organisational culture and organisation's external presentation are a tool to support innovations. Based on research results, suitable organisational culture:

- creates organisation's "image", provides and facilitates a clear view of an organisation, 
- increases organisation's attractiveness,

- creates and strengthens customer orientation, high quality of products and services,

- increases customer loyalty and satisfaction with organisation's products and services, and

- clarifies relationship between organisation and external stakeholders.

These results were also obtained by analysis made in this article. Organisations work with their culture for greater loyalty, strengthening relationships, better quality of work and improvement of organisation's climate.

In today's highly competitive environment, continuous and sustained innovation means not only innovation of products and processes, but also the development of human talents and management, as confirmed by the results that have shown the importance of setting the organisational culture in order to support knowledge and experience sharing among employees with a view to strengthening innovation potential of individuals, teams and the entire organisation, as was also evidenced by the research by Geradts and Bocken (2019), Chen et al. (2018), and Leopold (2019).

\section{CONCLUSION}

The organisational culture has significant impact on employee development as well as on their innovation potential. The research results show that organisation's focus on a particular type of innovation is influenced by the organisation's size and ownership. Innovations are supported in all sectors of Czech economy. Results identified two factors that characterise level of innovation potential based on employee development. Firstly, it is suitable setting of organisational culture to support collaboration ( $49.7 \%$ of the sample) and setting of organisational culture to support productivity ( $14.1 \%$ of sample). The first factor involves importance of high-quality relationships and communication among employees to increase the organisation's success and innovation potential. The second factor points to the approach of productivity increase through appropriate setting of organisational culture. Such elements operate as a significant mediator contributing to performance to manage innovation.

The results can improve practical approaches in defining the key criteria of building organisational culture and its efficient use to support innovations. The contribution of this paper lies in identification of approaches to organisational culture that may support innovation potential. The practical contribution lies in presenting concrete results from real organisations that redesigned their culture and identified efficient variables which affect the resultant approach to increase innovation potential. Application of approaches found by factors improves development of innovation and organisational culture. 
As a practical contribution, this paper suggests managers to realise the crucial elements of organisational culture, such as relationships, communication, and organizational climate, to improve performance by combining organisational efficiency in their strategic decisions made during the innovation processes.

The limits of the article may be seen in a relatively small sample of respondents; however, with respect to the stratified sample representing the real structure of organisations in the Czech Republic the sample can be stated as sufficient. The results may inspire other researchers to conduct further research in other conditions and deepen knowledge about relationship between organisational culture and innovation potential.

\section{REFERENCES}

Acebo, M.N. and Viltard, L.A., 2018. Corporate Culture: A Key to Stimulate Innovation. Independent Journal of Management \& Production, [e-journal] 9(3), pp.869-888. DOI: 10.14807/ijmp.v9i3.735.

Adams, R., Jeanrenaud, S., Bessant, J., Denyer, D. and Overy, P., 2016. Sustainability-oriented Innovation: A Systematic Review. International Journal of Management, 18(2), pp.180-205.

Anderson, V., 2009. Research Method in Human Resource Management. 2nd ed. London: Chartered Institute of Personnel Development.

Avolio, B.J., Walumbwa, F.O. and Weber, T.J., 2009. Leadership: Current Theories, Research, and Future Directions. Annual Review of Psychology, 60, pp.421-449.

Bocken, N.M.P., Short, S.W., Rana, P. and Evans, S., 2014. A literature and practice review to develop sustainable business model archetypes. Journal of Cleaner Production, [e-journal] 65, pp.42-56. DOI: 10.1016/j.jclepro.2013.11.039.

Büschgens, T., Bausch, A. and Balkin, D.B., 2013. Organizational culture and innovation: A meta-analytic review. Journal of Product Innovation Management, 30(4), pp.763-781.

Cerne, M., Jaklic, M. and Skerlavaj, M., 2013. Authentic leadership, creativity, and innovation: A multilevel perspective. Leadership, [e-journal] 9(1), pp.63-85. DOI: $10.1177 / 1742715012455130$.

Chai, D.S., Song, J.H. and You, Y.M., 2020. Psychological Ownership and Openness to Change: The Mediating Effects of Work Engagement, and Knowledge Creation. Performance improvement quarterly (Accepted for publication 05 February 2020). DOI: 10.1002/piq.21326.

Chen, Z., Huang, S., Liu, Ch., Min, M. and Zhou, L., 2018. Fit between Organizational Culture and Innovation Strategy: Implications for Innovation Performance. Sustainability, [e-journal] 10(10), 18p. DOI: 10.3390/su10103378. 
Corstjens, M., Carpenter, G. S. and Hasan, T. M., 2019. The Promise of Targeted Innovation. Mit Sloan Management Review, 60(2), pp. 39-44.

Czech Statistical Office (CSO), 2019. Inovace v českých firmách jsou na vzestupu. Védavýzkum.cz, [online] 06 November 2018. Available at: $<$ https://vedavyzkum.cz/politika-vyzkumu-a-vyvoje/politika-vyzkumu-avyvoje/inovace-v-ceskych-firmach-jsou-na-vzestupu> [Accessed 20 September 2019].

De Vaus, D.A., 2014. Surveys in Social Research. 6th edition. Routledge.

Diesel, R. and Scheepers, C.B., 2019. Innovation climate mediating complexity leadership and ambidexterity. Personnel Review, [e-journal] 48(7), pp.17821808. DOI: /10.1108/PR-11-2018.

Geradts, T.H.J. and Bocken, N.M.P., 2019. Driving Sustainability-Oriented Innovation Organizations Can Innovate to Address Environmental and Social Problems but They Need to Build the Right Culture. Mit Sloan Management Review, 60(2), pp.78-83.

Grinza, E. and Quatraro, F., 2019. Workers' replacements and firms' innovation dynamics: New evidence from Italian matched longitudinal data. Research Policy, [e-journal] 48(9), pp.1-1. DOI: 10.1016/j.respol.2019.05.013.

Hitka, M., Lorincova, S., Lizbetinova, L., Bartakova, G.P. and Merkova, M., 2017. Cluster Analysis Used as the Strategic Advantage of Human Resource Management in Small and Medium-sized Enterprises in the Wood-Processing Industry. BioResources, [e-journal] 12(4), pp.7884-7897. DOI: 10.15376/biores.12.4.7884-7897.

Hollensbe, E., Wookey, Ch., Hickey, L., George, G. and Nichols, C.V., 2014. Organizations with Purpose. Academy of Management Journal, [e-journal] 57(5), pp.1227-1234. DOI: 10.5465/amj.2014.4005.

Huo, D., Motohashi, K. and Gong, H., 2019. Team diversity as dissimilarity and variety in organizational innovation. Research Policy, 48(6), pp.1564-1572.

Jin, Z., Navare, J. and Lynch, R., 2019. The relationship between innovation culture and innovation outcomes: exploring the effects of sustainability orientation and firm size. $R \& D$ MANAGEMENT, [e-journal] 49(4), pp.607-623. DOI: $10.1111 / \mathrm{radm} .12351$.

Kampf, R., Hitka, M. and Ližbetinová, L., 2019. Direction of the Corporate Culture in Slovak and German Transport Companies from a Top Managers' Perspective. Periodica Polytechnica Transportation Engineering, [e-journal] 47(3), pp.213-219. DOI: 10.3311/PPtr.11166.

Kiron, D., Kruschwitz, N., Reeves, M. and Goh, E., 2013. The Benefits of Sustainability-Driven Innovation. Mit Sloan Management Review, 54(2), pp. 6973. 
Krejcie, R.V. and Morgan, D.W., 1970. Determining sample size for research activities. Educ. Psychol. Meas., 30, pp.607-610.

Lemon, M. and Sahota, S.P. 2004. Organizational Culture as a Knowledge Repository for Increased Innovative Capacity. Technovation, 24(6), pp.483-498. DOI: 10.1016/S0166-4972(02)00102-5.

Lenihan, H., McGuirk, H. and Murphy, K.R., 2019. Driving innovation. Public policy and human capital Research Policy, [e-journal] 48(9), 103791. DOI: 10.1016/j.respol.2019.04.015.

Leopold, H., 2019. Innovation through Culture and Communication. Elektrotechnik Und Informationstechnik, 136(3), pp.225-225.

Liao, Z., 2018. Corporate culture, environmental innovation and financial performance. Business Strategy and The Environment, 27(8), pp.1368-1375.

Lijauco, F., Gajendran, T., Brewer, G. and Rasoolimanesh, S.M., 2020. Impacts of Culture on Innovation Propensity in Small to Medium Enterprises in Construction. Journal of construction engineering and management, [e-journal] 146(3), 04019116. DOI: 10.1061/(ASCE)CO.1943-7862.0001753.

Martins, E.C. and Terblanche, F., 2004. Building Organizational Culture That Stimulates Creativity and Innovation. European Journal of Innovation Management, 6(1), pp.64-74. DOI: 10.1108/14601060310456337.

Messick, A., Borum, C., Stephens, N., Brown, A., Kersey, S. and Townsend, B., 2019. Creating a Culture of Continuous Innovation. Nurse Leader, [e-journal] 17(4), pp.352-355. DOI: 10.1016/j.mnl.2018.10.005.

Nidumolu, R., Prahalad, C.K. and Rangaswami, M.R., 2009. Why Sustainability Is Now the Key Driver of Innovation. Harvard Business Review, 87(9), 16p.

Sánchez-Báez, E.A., Fernández-Serrano, J. and Romero, I., 2019. Organizational culture and innovation in small businesses in Paraguay. Regional Science Policy and Practice. (Accepted for publication 15 February 2019).

Srisathan, W.A., Ketkaew, C. and Naruetharadhol, P., 2020. The intervention of organizational sustainability in the effect of organizational culture on open innovation performance: A case of thai and chinese SMEs. Cogent business \& management, [e-journal] 7(1), $1717408 . \quad$ DOI: 10.1080/23311975.2020.1717408.

Stachová, K. and Kachaňáková, A., 2011. Organisational Culture Analysis in Companies Operating in Slovakia. Scientia Agriculturae Bohemica, 42(2), pp. 87-92.

Stachová, K., Stacho, Z. and Vicen, V., 2017. Efficient involvement of human resources in innovations through effective communication. Business: Theory and Practice, [e-journal] 18, pp.33-42. DOI: 10.3846/btp.2017.004. 
Stankiewicz J. and Lychmus P., 2017. Corporate core values and professional values of Generation $\mathrm{Y}$ from the perspective of the effectiveness of ethics programs. Management-Poland, [e-journal] 21(1), pp.95-110. DOI: 10.1515/manment-2015-0082.

Urbancová, H., 2013. Competitive Advantage Achievement through Innovation and Knowledge. Journal of Competitiveness, [e-journal] 5(1), pp.82-96. DOI: 10.7441/joc.2013.01.06.

Wei, Y.L., Kang, D. and Wan, Y.Z., 2019. Geography, culture, and corporate innovation. Pacific-Basin Finance Journal, [e-journal] 56, pp.310-329. DOI: 10.1016/j.pacfin.2019.06.010.

\section{ABOUT AUTHORS}

Lucie Vnoučková - (L.V.) University of Economics and Management, Czech Republic, Department of Management, Assoc. Prof., e-mail: lucie.vnouckova@vsem.cz, Author's ORCID: 0000-0003-4296-875X.

Hana Urbancová - (H.U.) University of Economics and Management, Czech Republic, Department of Human Resources, Asst. Prof., e-mail: hana.urbancova@vsem.cz, Author's ORCID: 0000-0001-6603-8691.

\section{AUTHOR CONTRIBUTIONS}

All authors contributed equally to this article. L.V. and H.U. - conceptualization, resources, validation, writing review and editing.

\section{CONFLICTS OF INTEREST}

The authors declare no conflict of interest. The funders had no role in the design of the study; in the collection, analyses, or interpretation of data; in the writing of the manuscript, or in the decision to publish the results.

(C) 2020 by the authors. Submitted for possible open access publication under the terms and conditions of the Creative Commons Attribution (CC-BY) license (http://creativecommons.org/licenses/by/4.0/). 